Ssciendo Studia Anglica Posnaniensia 55 (2020): 403-426

doi: 10.2478/stap-2020-0020

\title{
OH CANADIANA? ATLANTIC CANADA, JOEL THOMAS HYNES, AND HEROIN REALISM
}

\author{
JASON S. POLLEY ${ }^{1}$ \\ Books? Fuck off \\ We'll All Be Burnt in Our Beds Some Night \\ Cause that's what we are, all of us, humans. \\ Even Johnny. \\ We'll All Be Burnt in Our Beds Some Night
}

\begin{abstract}
The essay locates Joel Thomas Hynes's We'll All Be Burnt in Our Beds Some Night (2017), narrated by the social outcaste Johnny, in an international "heroin realism" tradition. Hynes, styled as Canada's "bad boy" author, thus evoking his emotional ties to his protagonist, situates Johnny on the margins of Canada: in Newfoundland, which has been systemically disenfranchised from Canada's centre beside the rest of Atlantic Canada for over a century, as novels by Michael Crummey, Lisa Moore, David Adams Richards, Alistair MacLeod, and Hugh MacLennan show. The regionally representative Johnny complicates romantic figurations of Canada, which prides itself on progressiveness and equal opportunity, and which is globally envisaged as a beacon of mobility and community. Characters like Johnny do not fit into mythical Canada, whether in its pan-Canadian variety, where the East Coast is mythologized as an ocean oasis of what Herb Wyile calls "commercial antimodernism," or in its depressive, alcoholic Atlantic-Canadian version. Limited by his social positioning, ot unlike Rose in Alice Munro's collection The Beggar Maid (1978), Johnny cannot actualise the mobility Canadiana advertises - this despite his inculcation of this seductive delusion via books. He instead experiences what bell hooks calls "psychic turmoil": the discomfiture of simultaneously occupying two distinct yet continuous narratives. Johnny's regional narrative, then, not only translates to Rose's national one, as well as to the spirit of the Beats, of road novelists, and of Hunter S. Thompson's gonzo, but also to the international dimensions of other personages in "heroin realism." Writers like Joel Thomas Hynes, Harry Crews, Denis Johnson, Antonio Lobo Antunes, Jeet Thayil, Eimear McBride, and Niall Griffiths work to
\end{abstract}

1 Hong Kong Baptist University, Hong Kong. 
deconstruct romantic idealizations. The figures of heroin realism, like Johnny, are those characters who are neither commoditized by class relations nor by national narratives.

Keywords: Joel Thomas Hynes; Canadiana; Newfoundland; Atlantic-Canadian literature; heroin realism; psychic turmoil.

\section{Canadiana}

This essay is fashioned to dismantle the popular, international, nostalgic image of "Canada", a construction I condense in the term Canadiana. I aim, in other words, to destabilize naturalized dialectic divisions inscribed on the pastoral idyll of Canada, a place fashioned as global beacon of nature, kindness, and comfort. I position the social outcaste Johnny Keough - the problematic protagonist of Newfoundlander Joel Thomas Hynes's multiple award-winning 2017 novel We'll All Be Burnt in Our Beds Some Night (hereafter Burnt) - as a representative foil. Johnny, markedly, exists at the margins of a society that tends to pride itself on progressiveness and equal opportunities. Yet, as an Atlantic Canadian, the peripheral Johnny is by no means alone. Atlantic-Canadian literature and criticism, at least since the postwar period (so I will work to illustrate), has continued to undermine central configurations of Canadian self-conception (or, more precisely, Canada's own stereotypical self-image from the vantage point of Ontario's cultural capital of Toronto and federal capital of Ottawa). I chart Johnny's cross-Canada venture in light of other representative underclass Canadian figures, most notably the Ontarian Rose from Alice Munro's The Beggar Maid (1978). My mapping of regional, then national, outcaste experiences expands first to North America, where I consider Joel Thomas Hynes's inheritances from the road novel and gonzo journalism. In the spirit of gonzo journalism, I too assess Johnny's own rhetorical repositioning in Burnt, a novel where the juxtaposition of limited third-person and first-person points of view ultimately collapses in favour of the latter. As Johnny physically distances himself from Newfoundland, his emotional connection to the place, manifested in first-person, consolidates - even as the narcotized Johnny, not at all unlike Sweetland in Michael Crummey's eponymous novel Sweetland (2014), dies alone on a beach in hallucinatory beatitude. Johnny's position as social outcaste, I contend, proves at once personally unique, regionally emblematic, nationally representative, and globally applicable.

I come to present Burnt as an example of "heroin realism". "Heroin realism", so I construe it, subscribes to what Jesse S. G. Wozniak, quoting Jiron-King, calls "the gonzo dictate to not edit out the 'deformities' of real life" (Wozniak 2014: 470). The figures of heroin realism are neither commoditized by class relations nor by national narratives - nor are they aspirational figures concocted to provide 
identification-lessons in redemption. I implement "heroin realism" as an international literary categorization which humanizes social outcastes by stressing the experience of inhabiting simultaneously existing conflicting discourses and the "psychic turmoil" that ensues. I borrow my emotional havoc terminology from bell hooks's Teaching to Transgress (1994: 182). I cautiously (and sparingly) turn to the tools of critical race theory and critical whiteness studies (though these are not completely adequate to capturing the outcaste characters of Hynes and others) in order to signal Burnt's particular attention to other forms of social stratification beyond those configured by race. As John Hartigan, Jr. reminds us, "What matters with race is as much a person's class position as his or her individual 'opinions' and choices of whom to relate with" (1997: 203).

In spite of representative subalternity, heroin realism provides a spoken voice to members of a social sector more represented (spoken of) than self-representing (spoken by). The essay, concomitantly, is informed by the engaged work of the late Herb Wyile, who helped reorient my reading of Canadiana to Atlantic Canada. His nuanced and devoted critiques of Ottawa's neoliberal privileging of the interests of multinational corporations over the labour (and existential) interests of actual Atlantic Canadians, is evidenced in Wyile's Anne of Tim Hortons (2011) as well as a number of his late career essays referenced herein. As Wyile, quoting Conrad \& Hiller, sardonically says in his neoliberal analysis of Lisa Moore's February, "many Atlantic Canadians regret the abandonment of the noble dream that made human welfare rather than corporate profits the measure of civil society" (2010: 56).

As this essay moves from Canada's East Coast region all the way to the globe, which is one way to read what Herb Wyile \& Jeanette Lynes call the "cosmopolitan regionalism" of fiction by Newfoundland writers (2008: 12), a trope that pervades Atlantic-Canadian fiction and experience, I aim to sustain the wonderment of my wide-eyed first reading of Burnt. I initially approached the multiple-award-winning novel as a Canadian one. After further reading, my squinting critical perspective refocused to the field of Atlantic-Canadian fiction. I therefore hope to offer an analysis of Burnt that accommodates both the more general reader of world fiction as well as the more regionally savvy readers of Maritimes and Newfoundland fiction.

I have learned to agree with David Creelman's avowed contention that "the texts of Newfoundland embody a very different set of cultural and ideological tensions and must be considered as a regional literature distinct in itself" (2003: 3). This comprehension is partly shared by (at least) one of Alexander MacDonald's Dalhousie dentistry professors in Alistair MacLeod's No Great Mischief (1999). As he remarks on the poor dental-care statistics among the aboriginal population, in Quebec, and in the Maritimes, he says, "And Newfoundland. I never know 
whether to include it as part of the Maritimes or not" (1999: 97). In order to reconcile the context gap between specialists and wider trends in audience response (an interpretive community that - sadly - includes the general reader from "central" Canada), I elide these regional distinctions and refer to the Maritimes (Nova Scotia, New Brunswick, Prince Edward Island) and to Newfoundland \& Labrador collectively as Atlantic Canada.

Canadiana, so I conceive of it, exists at the stroppy intersection of imagined hope, experienced nostalgia, and cynical rejection. More than simply the sum of Canadian artefacts, artistic and historical, the spirit of Canadiana involves a subject's affective surrender to nostalgia, irrespective of the subject's critical awareness of the pratfalls of capitulating to this delusion. At the $8^{\text {th }}$ Congress of Polish Canadianists, held in Eódź in September 2019, the discussions in the panel "Reflections from Abroad: Constructions of Canadian Identity" revolved around this clash between naïveté (affective surrender) and sophistication (critical remove).

This Canadian experience of compromised realism was emotively evoked when a panelist screened a Tim Hortons commercial (krazykatie2006 2010) ostensibly narrated by a Canadian student at the University of Glasgow. Missing home, he and his roommate "James" recreate a "piece of Canada". Enveloped by pastoral images of the green Scottish glen (which insinuates an international image of Maritimes Canada as Scottish diaspora) and the welcoming sounds of what I can only describe as half-exultant folk music (perhaps a conservative mellowing of Nova Scotian fiddler Ashley McIsaac?), they transform their room into "Caribou House", replete with requisite Canadian ski chalet accoutrements: antique snowshoes, a Canadian flag dangling from a(n ice) hockey stick, a crucifix, a goalie helmet, a hockey jersey, a caribou trophy head, and assorted souvenir-quality mantelpiece bric-à-brac. Their place, we learn, "became known as the unofficial Canadian embassy here on campus", thus speaking to the global image of Canada as welcoming white-settler safe haven.

Despite my personal disdain for this Tim Hortons educed sponsorship of the Canadian imaginary, and for the general Tim Hortons believer-consumer overall (I recoil when I hear everyday references to "Timmy's" and "double-doubles"), the commercial had me desperately longing for "Canada". Indicatively, one of the public comments in the commercial's YouTube video-feed reads "this video totally makes me homesick .. [sic] and I'm not even Canadian". I posit Canadiana then, with the help of panelists Richard Nimijean, Christopher Kirkey, and Anne Trépannier, all of whom also examine Canada as framed internationally, as a lived experience of perverse affect. A mode that the paradox of fiction in part captures, Canadiana is that romanticized configuration we naturally surrender to, we innately suspend any disbelief of, all the while knowing we are alwaysalready invested in a romanticized (global) construction. 
In Burnt, Canadiana exists mainly in the negative. This is not to say, however, that Johnny, like every Canadian, does not experience recurrent visions or emanations of what I characterize as Canadiana. He, however, always derides himself for nostalgically surrendering to - and identifying with - these seductive temptations. Though "he feels a twinge of ... something ... deep down or right there on the surface or even outside of himself" as he "listens to Joanna's stories of calamity and sorrow and rising up out of the slummy backwoods of New Brunswick to put herself through university when everyone told her again and again that she'd never add up to shit" (Burnt 2017: 117), he begins the next paragraph by checking his naïve capitulation: "C'mon Johnny for the love and honour of Christ! Snap the fuck out of it brother" (Burnt 2017: 117). Some days later during his cross-Canada hitchhike Johnny finds himself in a vehicle with a weathered, recovered alcoholic named Jerome, who relates the death of his tenyear-old son a decade earlier; the boy drowned as the hungover Jerome napped in his truck by the pond. When he learns the boy would now be the same age as himself, "Johnny reaches out and lays his hand into Jerome's" (Burnt 2017: 161). Despite the subsequent unease that results from Jerome squeezing his hand in return, Johnny "wont pull away, he wont pull away cause it's the closest he's been to ... something ... in a long time" (Burnt 2017: 161, original spelling throughout). He reiterates his quixotic surrender: "something eases up in me, in Johnny" (Burnt 2017: 162). Half a page later, the next chapter of Burnt begins with the corrective "Fucken hell man, going around the country holding hands with old booze farts" (Burnt 2017: 163).

Johnny's self-recriminations might initially be understood as his own necessary performances of masculinity. He's a repeat offender after all, a personage who, if he was living in Alice Munro's West Hanratty, would run the streets with his underclass brethren: "casual bootleggers and prostitutes and unsuccessful thieves" (Munro 1978: 3). Johnny, though, illustrates that criminal camaraderie is not a suitable substitute for the social recognition the spirit of Canadiana promises. $\mathrm{He}$ recalls how one of his returns "back inside" is "not too bad, really. Easier, knowing the ropes, knowing the shortcuts, familiar faces. First time in Johnny's life he felt like he had a bit of community, for fuck sakes" (Burnt 2017: 145). Nevertheless, this reputed "community" only results from "Making up lies, tellin all about his trip to the Mainland to hang with Stevie the Scar. Toughest motherfucker ever tried on socks, man, no question" (Burnt 2017: 144-145). Johnny's disingenuousness with respect to his long-incarcerated father reveals itself directly. In lieu of subscribing to some romanticized outlaw narrative alongside Stevie the Scar, he envisions working-class near-normalcy: "Maybe Johnny could help wrangle up some interest in the case, be Stevie's man on the outside... . Get Stevie sprung finally. ... Maybe get a place together, settle in, be some sort of family. Dysfunctional? Yeah, more than likely" (Burnt 2017: 146). 
There's no immediate critical rejection of this image of paternity, domesticity, and optimism. No self-directed epithets. No rhetorical remove. Just battle-weary hopefulness, and a sense of novelistic closure. This projection of Canadiana compels Johnny to visit his infamous outlaw father for the first time. Tellingly, Johnny's delusions of domesticity quickly melt into air: "I can feel me weight shifting in the chair, my body tellin me to bolt for the door. I dont fucken need this. Some things, some people, they're best left up to the imagination. Youre better off not knowing, better off making it up as you goes along and then sticking to it. Take your delusions to the fucken grave like everyone else" (Burnt 2017: 189).

\section{Atlantic Canada}

Newfoundlander Joel Thomas Hynes's dialogic Burnt garnered, among others, Canada's Governor General's Literary Award for English Fiction in 2017. Hynes admits in a 2018 interview with YourTV Niagara, however, that he questioned whether the vaunted award was "a fluke or a statement being made by a big institution" (2018). His suspicion of national "academic" (YourTV Niagara 2018) acclaim left him "wonder[ing] if there is something larger at play having nothing to do with [his] book" (YourTV Niagara 2018). For Hynes, it is the BMO Winterset Award, provincially administered by the Bank of Montreal and the Newfoundland and Labrador Arts Council, that "is the most important [award]", the one that "allowed [him] to accept that [he] had won the Governor General's Award" (YourTV Niagara 2018). Here, the political and artistic tensions between centre and periphery, between Mainland Canada and Atlantic Canada, are patent.

In "Going Out of their Way" (2008), Herb Wyile reminds readers of the "lingering sense of grievance" (162) experienced by Newfoundlanders. Newfoundland, Wyile reminds us, was the only Canadian province to achieve semi-autonomy in the early 1900s (2008: 162). Yet "Newfoundland was forced to surrender that status in 1934 in the midst of a fiscal crisis brought about by various economic and political factors" (Wyile 2008: 162). Wyile notes how the "ensuing convention and referendum on Newfoundland's constitutional future", leading to the province's "entry into Confederation in 1949", for many "constituted a hijacking of Newfoundland's autonomy" (2008: 162). Newfoundland shares this lived historical grievance with the Maritimes. Wyile highlights "the structural inequalities and regional disparities ensuing from such a centralized national policy" (2008: 162-163), one with its own biased "“national' economic priorities" (2008: 163) alongside a "double standard in economic policy: what's good for central Canada is 'national' and what's good for Atlantic Canada is 'regional"' (2008: 163). Wyile elsewhere plainly phrases this as "the privatization of profit and the socialization of loss" (2013: 30). In 
"Surf's Up! The Rising Tide of Atlantic-Canadian Literature" (2008), Herb Wyile \& Jeanette Lynes recall how this self-serving economic illogic historically marginalizes East Coast writers: "for most of the [twentieth] century the region's writers were eclipsed by those in the rest of the country, particularly in 'central' Canada" (2008: 7). "For much of the century," Wyile \& Lynes continue, "writers from the east were faced with the choice of relocating to the centre ... or sticking it out on the margin" (2008: 7).

In a paratextual move that would not have escaped the eyes of Gérard Genette (see Paratexts 1997), Hynes laterally addresses the historical (and ongoing) subjugation of Atlantic Canadians generally, and Newfoundlanders specifically, by inscribing the following in bold at the top of Burnt's copyright's page: "This book is dedicated to the myth of the friendly Newfoundlander" (2017: np, original emphasis). The engraving is at once cryptic and telling. Members of a more broad reading audience might pursue a number of questions in light of the dedication. Might the author be suggesting that the existence of "friendly Newfoundlanders" is a myth? But why construct such a legend? To what purpose? And what, anyways, is it to "dedicate" a "book" to a "myth"? Supplemental interrogations apply if we accept the paratextual proposition unironically. Perhaps Hynes really is thankful for "the myth of the friendly Newfoundlander", whether the myth applies to all Newfoundlanders, to friendly Newfoundlanders, or to the single instance of "the friendly Newfoundlander". Even if we read this "dedication" as an inside joke, as the author's collective's assent to sardonically decry those who just don't or can't or won't get it, the "dedication" still posits the existence of a state of affairs, of a mythologized image from Canadiana, in this case that of a meagre yet merry erstwhile fisherman, that requires rigorous deconstruction.

At the close of her Burnt book review (2018), Melanie Hurley, of Newfoundland's Memorial University, is careful to highlight how her "peculiar reading context" does not "reflect broader trends in audience responses" (2018): 287). Hurley's particular perspective includes an existential familiarity with the fact that "books by Newfoundland writers tend to be explicitly about life in this province, albeit in different historical periods" (2018): 284). Hurley goes on to address Burnt's "connections to the local at the level of quotidian details and at the level of the Newfoundland literary corpus," both of which make "the novel's world hauntingly, and perhaps distressingly, familiar to long-time residents of the province" (2018): 284). Hurley is literally linked to the Hynes local; she too harbours in Canada's geographical peripheries. This subaltern East Coast experience, which Wyile \& Lynes liken to feeling like a mere "appendage" to "the national imagination" (2008: 8), conditions Hurley to also approach Hynes's Governor General's Award with a degree of suspicion. The award, of course, introduced extradiegetic complications to her appraisal of Burnt (Hurley 2018): 
283). But Hurley's key takeaway emotionally echoes Hynes own response to receiving the award: "I believe that [Burnt] is worthy of the Governor General's Award, but I also think it is a controversial text" (Hurley 2018): 287). She qualifies the award, just as Hynes needed it qualified. Knowing how the federal government has subjugated their province, not to mention the rest of the Maritimes, both evince an innate distrust of the motivations of "central" Canada.

Hurley's deft observation concerning Burnt's connection to the Newfoundland canon affords a nuanced, albeit still speculative, reading of Hynes's bold-faced copyright's page testimonial, a reading that speaks to the romanticized Newfoundland imaginary Hynes works to deconstruct. A quarter century before the publication of Burnt, E. Annie Proulx included the following in the "Acknowledgements" page at the beginning (in lieu of at the end) of her Pulitzer Prize - and National Book Award-winning "Newfoundland novel" The Shipping News (1993): "The Newfoundland wit and taste for conversation made the most casual encounters a pleasure" (np). Proulx's thankful words, though graceful and sincere, could, if read uncharitably, and without the framing context of The Shipping News itself, be understood to be those of an "'external' [who is] objectifying stereotypes", if I can somewhat uneasily appropriate from Ian McKay's The Quest of the Folk (1994: 31). McKay - who's writing specifically about Nova Scotia, thus my apprehensive qualifier - details the processes by which 20th-century "tourism, folklore, and handicrafts" transformed "the people of the fishing villages" into "bearers of Nova Scotia's cultural essence: they became archetypal Nova Scotians living not on a barren patch of Atlantic shoreline, but on a mythified 'Coast of Songs', which rang with their ballads and merriment" (1994: xv-xvi). McKay christens this "local variant" of hegemonic Atlantic-Canadian antimodernism "Innocence", which he explains as "a kind of mythomoteur, a set of fused and elaborated myths that provided Nova Scotians with an overall framework of meaning, a new way of imagining their community, a new core of a hegemonic liberal common sense" (1994: 30). "Innocence", to return to my first usage of McKay several sentences above, "blurred the distinction between 'internal' local knowledge and 'external' objectifying stereotypes" (1994: 31).

Perhaps Hynes takes issue with what he construes as Proulx's own "innocence". After all, Proulx's acknowledgements can be mined to provide a symbolic, nostalgic list of bucolic appurtenances, including "a dog bite", "Newfoundland home cooking", "the complexities and strengths of Newfoundland women", "fishermen and loggers", "wind, bears, and mosquitoes", and "an April storm, icebergs and caribou" (Proulx 1993: np). A mordant or even animadverse reader, like Hynes's multiple-felon protagonist Johnny, might summarize Proulx's acknowledgement as bolstering the positive side of the Atlantic Canada paradigm, as effectively saying, in other words, that 
"This book is dedicated to the myth of the friendly Newfoundlander". Certainly, the unforgiving actualities of The Shipping News itself counter any configuration of Newfoundland as pastoral idyll. Passages like "the goddam Canadian government giving fishing rights to every country on earth, but regulating us out of business" (Proulx 1993: 65); "There is more government in Canada than any other place in the world. Almost half the population works for the government and the other half is worked on" (Proulx 1993: 68); and, "Now the fish is all gone and the forests is cut down" (Proulx 1993: 199) call to mind the sustained critique of exploitative neoliberal labour conditions under multinational corporations that Herb Wyile later fashions into Anne of Tim Hortons: Globalization and the Reshaping of Atlantic Canadian Literature (2011).

Wyile characterizes the Atlantic Canada paradigm as a "slippery concept" because it "takes two seemingly contradictory but ultimately complementary forms" (in Thompson 2015: 184). On the one hand, East Coast Canada is conceived as ocean wonderland, where the "region's way of life [i]s frozen in time, idyllic, and rooted in the land and the sea, innocent, untouched by technology and authentic" (in Thompson 2015: 183). On the other hand, "constructions of the East Coast" mark the same geographic region as "Canada's social, economic, and cultural basket case, populated by alcoholic deadbeats, welfare mothers and rockbound trailer trash" (in Thompson 2015: 184). The 12 season-long TV mockumentary Trailer Park Boys, created by Mike Clattenburg, and directed by him for the initial run of seven seasons of the series, capitalizes on these two intertwined Maritimes constructions. Featuring a foul-mouthed, petty felon, trailer-park-trash cast, the program offers "an ironic take on the most extreme versions of the region's culture in that it depicts Nova Scotia in a way that is radically different (and perhaps more appropriate) than what has appeared on the CBC and elsewhere" (Thompson 2015: 182-183). Ostensibly absent from Trailer Park Boys is what Thompson, appropriating Wyile, understands as a nostalgic national narrative systemically evoked by the Canadian Broadcasting Corporation (CBC): a "charming, picturesque, and welcoming version of [Maritimes] folk - the folk as wise fisherman and storytellers - propagated by tourism brochures and advertisements for Alexander Keith's beer" (in Thompson 2015: 184).

The underclass culture of Trailer Park Boys, still, is sanitized. The faux documentary, like a host of twenty-first-century sitcoms, is mediated through the lens of what Brett Mills would call "comedy verite" (in Thompson 2015: 188). While this genre collapse proffers a host of "comic inversions and recurring slippages, from cliché to archetype and back again", thus producing "a text that is, in the Bakhtinian sense, truly 'double voiced"', when all is said and done Trailer Park Boys is "hard to take seriously" (Hughes-Fuller 2009: 106). Despite its 
apparent resistance to what McCullough would label "regional commoditization" (2009: 155), something televisually internalized in the Canadian imaginary due in part to "'Maritime' programming such as Road to Avonlea" (Hughes-Fuller 2009: 105), Trailer Park Boys likewise fetishizes the bedrock archetypes of the Maritimes folk paradigm. The underclass figures of Julian, Ricky, and Bubbles, each of whom starred in all of the series' 106 episodes, exist in stark relief to their similarly socioeconomically situated East Coast cousin Johnny Keough, not to mention the cast of other mainly criminal characters Johnny is forced to associate with in the streets and in detention centres.

Trailer Park Boys proves double voiced because it can afford to treat serious incidents non-seriously. Though they are repeat felons, Julian, Ricky, and Bubbles, who regularly talk to the amateur film crew documenting their typically marijuana-related moneymaking schemes (this predating legalization nationwide of cannabis in Canada in 2018), remain likeable, even approachable. In this respect, the boisterous "Boys" of Sunnyvale manifest as contorted versions of the male members of the hardscrabble clann Chalum Ruaidh in MacLeod's No Great Mischief. MacLeod's Cape Bretoners, however, travel Canada and the world for work, thus revealing the East Coast region as, to appropriate Wyile's locution from Anne of Tim Hortons, a "pool of reserve labour for other parts of the country" (2011: 56). Clattenburg's characters, of course, somehow manage to remain in and around Sunnyvale. They have a stable sense of place. Though Sunnyvale Trailer Park is awash in garbage due to trailer park mismanagement as season two opens, we understand that this aesthetic anomaly will be corrected. We read the refuse negatively: its presence speaks to the park's regular (relative) tidiness. Though parodic, though countercultural, though genre-redefining, there is a conservative sense of safety, of connection, in Sunnyvale. Ironically named or not, Sunnyvale is a community (one that also exists non-fictionally), a place that residents - and TV viewers - always can return to.

Patricia Hughes-Fuller points out that "Trailer Park Boys represents a kind of anti-pastoral" (2009: 105). Because the long-running show is "Immersed in urban sleaze", she explains, "Trailer Park Boys seems distinctly out of step with other media representations of the region" (Hughes-Fuller 2009: 105). We could argue, though, that the "kind of anti-pastoral" that Trailer Park Boys fashions is likewise "a kind of" pastoral. The show's emphasis, when all is said and done, is the social capital of community. Most every season begins with one or more cast members returning from incarceration to Sunnyvale, to their vehicles (which sometimes double as houses), to their friends, to their rivals, to their community. Particularly earlier in the series, several episodes are punctuated by the leitmotif of Ricky's "Knock-knock" joke, one that invariably results in him exclaiming "Fuck you" as he brandishes his middle finger to the episode's perceived most oppressive figure. Whether Ricky directs this routine riposte to a deadpan police officer, to 
drunken Park Manager Mr. Leahy, to his shirtless underling (his on-again-offagain always shirtless boyfriend) Randy, or to one of Julian's passing girlfriends, the result is invariably the same: an amused viewership conditioned to rally behind Ricky's anti-authoritarianism, evidenced in my living room at least by me shouting the "punchline" in sync with Ricky. As such, there's an established community of viewers united in their comical reaction to Ricky's ready rage.

This viewing collective is not just a Canadian national one, if the proliferation of Trailer Park Boys feature-length spinoffs available on Netflix (including an animated series) is a reliable indicator. What we presumably have, then, is an international community of spectators - one abetted by Hip hop icon Snoop Doggy Dog's cameos over the last seasons of the series - enjoined to be entertained by Ricky's recurrent reaction to class exploitation. Ricky himself isn't at all entertained. As we contort ourselves in collective laughter, he remains deadpan. A version of this affective disjunction opens Alice Munro's short story "Privilege" (1978). Rose, who's physically but not psychically escaped West Hanratty's underclass hinterlands by qualifying for secondary school in middleclass Hanratty, recognizes that the horrid outhouses of her neighborhood "were supposed to be comical - always were, in country humor - but she saw them instead as scenes of marvelous shame and outrage" (Munro 1978: 25). Rose's immediacy prohibits rhetorical distancing. The pastoral trope re-inscribes humiliation and indignation for spectacular consumption. Either way, as figured in pastoral and anti-pastoral alike, individual experience is rejected in the service of a frozen or timeless distantiation, one where unique agency is supplanted by hackneyed archetype.

\section{Joel Thomas Hynes}

In "Newfoundland, which has a small population", the multidisciplinary artist Hynes avers, "the industries are not huge so there's only so far you can go" (Carter 2017: np). The working-class actualities of Newfoundland \& Labrador as we also learn in Lisa Moore's February (2009), which deals with both the immediate and decades-later emotional consequences of the sinking of the Ocean Ranger offshore drilling unit that drowned all 84 crew members on 15 February 1982, a night after which "Every soul in the whole province kn[ew] exactly where they were" (2009: 8-9) - highlight "the exploitation of economic desperation" (Wyile 2010: 70). Wyile clarifies how February "situates the seemingly singular [Ocean Ranger] event in the broader culture of corporate austerity, lack of regulation, and manipulation of the public" (Wyile 2010: 70). Inured to what Lisa Moore describes as "Odd jobs and cobbling a life together" (Moore 2009: 116), Hynes plainly acknowledges that "You can't just be one thing in Newfoundland" (in Carter 2017: np). A live testament to his contemporary Newfoundland work- 
life apostrophe - which integrates what Newfoundlander Michael Crummey in his novel Sweetland calls a diaspora of "Economic refugees mourning the anachronistic little world they'd abandoned" (2014: 234) - Hynes himself is a musician, poet, playwright, filmmaker, actor, and author of four novels. The ominously titled Burnt charts the fated trajectory of repeat-offender John Joseph Keough (a near anagram of Joel Thomas Hynes), an early 20s have-not so institutionally disempowered that his court-appointed lawyer can recall neither the details of his juvenile and adult rap sheets nor the correct pronunciation of Johnny's surname (it's the monosyllabic "kjeof", not the disyllabic "kee-oh").

Johnny has little say in his own official narrative. We might thereby say that he recalls the lost-at-sea Sri Lankan refugees that Sweetland rescues near the remote isle that carries his overdetermined name in Sweetland (2014). Yet Johnny only resembles these "ghostly arrivals" tropically (Crummey 2014: 25). Johnny, a Newfoundlander, speaks Newfoundland's lingua franca, just like Sweetland, who's "people" have lived on Sweetland, he offers, since "Time before time" (Crummey 2014: 9). The irony, of course, is that Sweetland too is a refugee - and this on his own ancestral land. Newspaper headlines like "Newfoundland Fisherman Rescues Sri Lankan Boat People" (Crummey 2014: 187) fetishize the rugged naturalism of a water-bound vocation and lifestyle that the central government has, for all intents and purposes, legislated into inexistence. Since the cod moratorium in 1992, Sweetland has been a impoverished fisherman; in one passage we learn "it was still shy of noon when [Sweetland and Jesse] made their meagre quota" (Crummey 2014: 131). Like everyone on the isle, Sweetland is also being disenfranchised from his home: the central government has placed a moratorium on all essential services on, including the ferry itself to, Sweetland.

The distance between the triumphant newspaper headline and the lived realities of Newfoundland fisher-folk like Sweetland calls to mind the mental exercise that McKay performs regarding the title of an 1890s postcard purportedly depicting a seven-person family living in the archetypal landscape of St. Margaret's Bay, near Halifax. Our reading of the photo championed as "a 'realistic' representation of the "way things used to look" (McKay 1994: xii) changes markedly as we alter the original title from "A Simple Life, House 8 x 10 Mill Cove N.S." to "The Heathen Poor upon Our Coasts" or to "Starvation and Suffering through Capitalist Underdevelopment" (McKay 1994: xiv). What this exercise exposes, even in contemporaneity, to use Wyile's words, is a blatant "repackaging [of] the region as unspoiled and culturally distinctive rather than underdeveloped and backward" (Wyile 2008: 164). Johnny, like Sweetland, who derides the Sisyphean task of reading books about his province featuring blurbs by "a Toronto paper about 'authentic Newfoundland"' (Crummey 2014: 206), is not devoid of class consciousness; he's not a mere dupe. He apprehends his institutional silencing. 
The prima facie conceit of Burnt, after all, is Johnny's Canada-wide escape from his criminal and outcaste experiences in the East Coast netherworld of Newfoundland. Evoking the compromised promise of Canadiana, Johnny interprets his criminal positionality concretely in terms of territory, not abstractly in terms of theory. As an ex-con on the lam from both the law and his drug-dealer, Johnny absconds to "the Mainland" - which is how Atlantic Canadians refer to the rest of Canada; Canada, a place, Hugh MacLennan reminds us in Barometer Rising (1941), that is tied to Halifax, Nova Scotia, by nothing more substantial "than a single main highway, a railway track, and a string of telegraph wires" (1941: 247) - in order to "vanish" 6000 kilometers and "toss" the ashes of his exgirlfriend Madonna "into the wind" of the opposite coast. "[O]ut there", so Johnny erratically reminisces, nostalgically surrendering to an uncomplicated version of their past, "on that beach she was always on about, what was the name of it? Something religious? Jeremiah? Maybe track down this sister Dana. Danielle? Go Johnny. Go now. Go. Right across the country. Run to a cab stand and get out on the TCH and bloody well vanish" (Burnt 2017: 74-75). Johnny envisions the Trans-Canada Highway as gateway and escape. Like a host of celebrated literary personages before him (if not the actual exodus of many Atlantic-Canadian economic migrants before him), freedom entails physical movement. Recall, for instance, Margaret Laurence's regionally coded thirtysomething Rachel in A Jest of God (1966); the schoolteacher appears finally to evade her mother's untiring surveillance by securing a job on Canada's West Coast.

Though the road trip trope is not novel to postwar North American culture, "the open road," as lionized in literature, film, and music, remains a distinguishing feature of the North American imaginary. While Jack Kerouac continued to labour over how to ceremoniously translate his repeated crossAmerica hitchhiking derring-do into On the Road (1957), Vladimir Nabokov insinuated himself into the American literary scene by fashioning Lolita (1955) partly as a road novel. And at the same time as Hunter S. Thompson burlesqued the failures of the 60s counterculture in the genre redefining Fear and Loathing in Las Vegas (1971), which opens with a road trip in medias res, Don DeLillo inaugurated his writing career with the road novel Americana (1971). Burnt, however, is not a distillation of these American tropes nudged northward. Burnt is neither countercultural escapade nor petit bourgeois confession nor lampoon of legislated violence nor top-down critique of reliability. Instead, Burnt encodes an alternate Canada, one that outstrips emblematic figurations of Canadiana. Burnt humanizes, and thereby demythologizes, Canada's remote East Coast regions, namely the falsely "folksy" Atlantic provinces generally presented from diametrically opposed views: as timeless, pastoral idylls or as depressive, regressive badlands. 
Johnny's urgency, his will to abscond, his self-directed "Go Johnny. Go now. Go" (Burnt 2017: 75) can be understood as an outcaste instantiation of the East Coast working-class fiat to be mobile, perhaps most evocatively captured in MacLeod's No Great Mischief. David Creelman affirms this normalized working-class transiency, these "continual departures" from the Maritimes, as yet "another source of disruption for the traditional local community" (Creelman 2003: 13). Unlike his author, Johnny, of course, has no recognizable local community. "For a good chunk of the year", Hynes himself exercises this physical mobility: he "lives in a flat in Toronto's Beeches neighbourhood" (Carter 2017: np). Hynes escapes to the Mainland - to the centre - regularly. But we might rebrand this spatial relocation. Hynes, in fact, annually returns to Newfoundland for a small chunk of time. His movements therefore mirror those of a host of his Atlantic-Canadian literary precursors who secured their modicum of fame away from home. Upon his annual arrival to Newfoundland, the returned native straddles his "motorcycle and heads to his small house in the woods", a place where "No one comes around", a refuge where he "live[s] a very, very simple quiet existence for a couple [of] months" (Carter 2017: np.).

So far, Hynes's novels remain rooted in the same Newfoundland "milieu", one immediately "recognizable" on account of its "immersive colloquial language" (Carter 2017: np.). "[B]ig city" life, even the likely cosmopolitan one Hynes shares for most of the year with his teenage son, the actor Percy Hynes White, has so far not redirected Hynes's novelistic penchant to depict masculine "antiheroes", each with a "predilection for booze, drugs, and destructive relationships" (Carter 2017: np.). Since Hynes continues to submerge his key characters in the coarse environment of Newfoundland, he continues to be at least partly conflated with these credible fictional figures and the sorts they traffic the streets with. This elision between character and author evidences the author's realist familiarity with the underworld themes he so acutely depicts. The fierce and gritty nature the naturalism - of Hynes's career-long representation of destitute Newfoundland has earned him "an international reputation as a bad boy of Canadian literature" (Carter 2017: np.). In this sense, though early in his career, we might consider aligning the young Hynes with the accomplished New Brunswick writer David Adams Richards, whose "imagined New Brunswick is not romantic, idyllic, or sentimental, a fact that has been consistently highlighted by clearly offended reviewers of his work" (Tremblay 2008: 32). One such critic, Tony Tremblay reports, concluded that Richards's "fiction is as emotionally draining as a month of funerals" (2008: 32). Given that East Coast fiction tends to feature funerals every Atlantic-Canadian novel so far mentioned in this essay includes at least one plot-driving funeral - Richards likely accepts such a comment as an encomium. As he writes in Mercy Among the Children, "if you are born in a shack near someone who wants your land, dislikes your presence, covets your wife, is 
angered by your marriage, you are in a part of the world millions and millions see and have no course to redress" (Richards 2000: 40).

Especially because Hynes is a Canadian, which globally translates to a lucky national swaddled in the wholesome modern mythoi of uncomplicated kindness, the natural environment, and progressive international diplomacy, his global "bad boy" designation ironically risks being offset by romanticized enfant terribletype configurations. As a Newfoundlander, Hynes is certainly no stranger to asymmetrical power relations. Before he garnered the Governor General's Award, Hynes admits to having "received pressure to try a different style or setting to avoid a reputation as a regional writer" (Carter 2017: np). Though Hynes was nationally awarded for depicting the underworld realities of a place he "loves", his suspicions about the top-down motivations behind this "awarding" indicate that he'll have to continue resisting the national interpellation that, to repeat Wyile, amounts to "a hijacking of Newfoundland's autonomy" (Wyile 2008: 162). After all, the "bad boy" of Canadian letters continues to expose what Wyile calls "the slippery concept" of Canada's maritime "folk paradigm" (in Thompson 2015: 184). For Hynes, his characters, and his growing readerships, the Newfoundland locus offers a pregnant riposte to romantic Canadiana. The Maritimes and Newfoundland loci of Hynes, his peers, and their predecessors, complicate lasting folksy East Coast televisual innocence. Hynes's Newfoundland is neither bucolic nor redemptive. Nor is it timeless - or evolving. The outcaste Newfoundland that Hynes conjures undercuts Canadiana. In lieu of situating a regressive Newfoundland in stark relief to the progressive mainland, Hynes's bottom-up lens refocuses readerly attention to dispossessed figures in Atlantic Canada and across Canada, as well as around the world.

Hynes counters the institutional "pressure" to move away from his regional Newfoundland representations with retorts like "Roddy Doyle has Ireland, David Adams Richards has the Miramichi and Annie Proulx has Wyoming ... . Why can't I have Newfoundland and set my writing in a place that I love?" (Carter 2017: np). Besides an obvious reference to Yoknapatawpha, the apocryphal Mississippi county where Faulkner sets most of his fiction, Hynes may also have, were he not referencing only living authors, mentioned Margaret Laurence and her five Manawaka novels. Before Hynes, who sets his fiction in small-town Newfoundland despite no longer living there full-time, Laurence's preferred setting remained in fictionalized, small-town Manitoba, a province where she no longer lived. Perhaps more telling than Hynes's admittedly affective justification for situating his fiction in Newfoundland is that, despite Burnt's pan-Canadian road-trip conceit, the novel in many ways remains a regional one. Yet the human landscape Hynes highlights is as much socioeconomic as it is geographic. Yes, the 23-year-old Johnny travels coast-to-coast across "the Mainland". But Johnny, not unlike his author, remains fundamentally rooted to Newfoundland, a place 
even few Canadians seem to know beyond normalized narratives about dead fisheries, high taxes, inveterate alcoholism, and "Newfie" jokes. And Burnt makes no gesture toward redeeming or sanitizing this Canada-wide bourgeois (or top-down) indictment of Newfoundland.

Johnny, whom Hynes "refers to as a sociopath" (Carter 2017: np), is not conceived to offer a paean to or panacea for or any correction of collective Newfoundland (and Maritimes) condescension. I read Hynes's description of Johnny as a "sociopath" ironically because though Johnny exhibits several charted sociopathic attributes - aggression, recklessness, rage, irresponsibility, criminality, and limited social attachments - to dismiss him as "a personality disorder" (Burnt 2017: 141) is to reproduce his juvenile detention-centre jailer McGregor, who once told the teenage Johnny he was "a fucking little sociopath" (Burnt 2017: 141). Johnny recalls candidly looking up the condition "in a dated medical text", which prompted him to "look up the word empathy too" before "slamming the heavy text shut when he feels McGregor's eyes scanning him" (Burnt 2017: 142). Johnny's cathexis, as experienced through literal panoptic surveillance, at first finds him remembering his Uncle Austin "shaking him back and forth like a scarecrow" by his lapels while calling him a "Fucken abomination!" outside the funeral home after his cousin and best friend Mikey's suicide (Burnt 2017: 142). Even a decade later, Johnny remains fixated on his "disorder", a condition Hynes attributes in Burnt not to Johnny's psychological constitution but rather his socio-regional positioning. Disease registers here as dis-ease: a consequence of being a scapegoated and disciplined marginal subject. As Michael Zweig reminds us, "Class is about [the] power some people have over the lives of others" (in Beech 2004: 175). Readers, prompted by Hynes, invest in Johnny because his actions are symptomatic of a naturalized neoliberal process of disempowerment, one that extends beyond the borders of East Coast Canada.

\section{Heroin realism}

Reviewing Hynes's poetry volume Straight Razor Days (2011) in light of the multi-talented Newfoundlander's overall literary oeuvre, Adam Beardsworth opines the writer's "familiar (and somewhat tainted) well of images and characters, complete with petty thieves, substance abuse, street fights, piles of shit, blood, and the relentless posturing of a persona eager to affect bravado as substitute for identity" (2012: 140). Beardsworth extends his "tainted familiarity" critique to the style of Hynes's writing. To wit, "diction that reflects vernacular speech patterns and forgoes technical innovation or prosodic virtuosity" (2012: 140). He then implements the same conservative diminution of underclass belonging that Hynes works to expose. "The foremost concern of Hynes's persona", Beardsworth avers, "seems to be what others have done to him" (2012: 143). In an interview with 
Hynes three years earlier (2009), Michelle Butler Hallett offers a diametrically opposed reading. She sees Hynes's "prose, even with the most profane language and sordid imagery, [a]s poetic" (Butler Hallett 2009: 121). She furthermore lobbies against the superficial accusation of carnivalism that Beardsworth comes to levy. The figures that Hynes has "tell their stories", "discard" figures unsuitable for convenient "slotting ... into some authorial moral reckoning", Butler Hallett attests, "are no stage rejects, no buffoons trotted out at some literary freak show. They are human beings, as driven, tormented, broken and hopeful as humans everywhere" (Butler Hallett 2009: 121). Butler Hallett likewise uncovers a patent source of Hynes's vernacular style. "I was reading a lot of Kerouac and stuff", Hynes clarifies, and "I just realized you could write as you saw your life" (Butler Hallett 2009: 122). Later in the interview, Hynes reluctantly addresses the type of street detritus that Beardsworth later labelled as mere affectation in the author's work: "But I guess I put all that stuff in the manuscript, almost so I could have a normal life. Because if I'm not working - writing - then I generally am all that shit" (Butler Hallett 2009: 126).

Hynes accentuates his own experiential connections to those of his difficult hero Johnny. "The story is not autobiographical", Hynes avers, "though elements certainly are" (Butler Hallett 2009: 126). He likewise "maintain[s]" that Burnt is "emotionally true" (Butler Hallett 2009: 126). Paraphrasing Wayne Johnston's response to critiques of his historical representation of Newfoundland in The Colony of Unrequited Dreams (1998), Adam Lawrence stresses that "strict reliance on the historical record can rob a narrative of its emotional poignancy" (Lawrence 2010: 130). Even if Hynes's limning of that emotional space falls within the parameters of what Beardsworth dismissed as a form of familiar or vernacular romanticism, Johnny's own de-romanticization of the antipastoral speaks to the fragility of even working-class familiarities in Newfoundland. En route to the Kingston Penitentiary - the same institution that confines Cape Bretoner Calum MacDonald after he kills a Québecois coworker outside a Sudbury mine in MacLeod's No Great Mischief; the nationally famous nowformer maximum security prison literally located at the nexus of mainland disciplinary authority - where his father is imprisoned, Johnny stands "lookin at them gulls circling, scavenging rich mainlanders' garbage bins and you wanna shoot em all" (Burnt 2017: 174). "Remind you", says Johnny explaining his vehemence, "of home in a different way, before they told us we couldnt catch a fucken fish no more. When there was money on the go, good work on the go, and peopled seemed settled and content. Not what came after, after even the gulls fucked off - fucken misery. Whole other level to the booze. Like the whole town shifted overnight" (Burnt 2017: 174). Johnny and Hynes, irrespective of economic background, share the poignant emotional consequences of that overnight town shift to "fucken misery", one rendered starker in light not only of 
habitual nostalgic review but also of inconceivable legal circumstances. As we recall Jack Buggit's "The damn foreign trawlers" in The Shipping News (1993: 65), we too remember the territorial isles of St. Pierre and Miquelon, nearby the equally remote isle of Sweetland, where Sweetland remarks "The French were still allowed to fish for cod" (Crummey 2014: 165).

Addressing this "other level" of Dickensian misery, one systemically in operation in the Atlantic region for over a century - McKay, for instance, soberly notes that "very few, if any, Nova Scotians would have qualified [as actual, pastoral Folk] by the 1920s" (McKay 1994: 28)! - in anything but a style that Beardsworth labelled as "dirty" would itself come off at a far remove from miserable social actualities. Beyond Bukowski and Carver, the writers Beardsworth credits with influencing Hynes's persona in his Straight Razor Days review (Beardsworth 2012: 140), Johnny's layered narrative voice in Burnt at once calls to mind the countercultural rampages of realist (Beat Generation) writers like Burroughs and Kerouac in the 1950s and 1960s, as well as the feverish, participatory excesses of Hunter S. Thompson's gonzo journalism in the 1970s. Yet unlike his half-coded lionized literary precursors "William Lee", "Sal Paradise", and "Dr. Raoul Duke", the similarly substance-addled down-and-out Johnny - just one of growing townfuls of the dispossessed - does not have the bohemian cachet of university experience, nor a community of like-minded countercultural outcastes. Even though Johnny "howls" through the first half of Burnt (2017: 52, 99, 114), he can't manifest the refined underclass deconstruction of corporate control mechanisms championed by Ginsberg's most famous persona. And this is not just an oblique way to discard Johnny on account of his alternate literacy.

Johnny, in fact, anticipates such top-down dismissals. He includes a quarterpage list from the "thousands" of books "Johnny[s'] ripped through", including everything from The Waste Land to The Handmaid's Tale to A Guide to New York City Restaurants to The Weekend Mechanic (Burnt 2017: 103). Johnny's reading list, in a move that continues the novelist's inherited dismantling of the politics of the centre, veers away from the more classically canonical novels referenced by Neil Macrae in Hugh MacLennan's Barometer Rising (1941), Alex Macdonald in MacLeod's No Great Mischief (1999), and Owen Jameson in Richards' The Friends of Meager Fortune (2007). Like Sydney Henderson's collection of books, which are piled everywhere in his destitute house in Richards' Mercy Among the Children (2000), Johnny's cultural consumption of books stems from genuine curiosity, not formal education. Also discrediting any easy debunking of his reading list, Johnny includes personal synopses of (i) Barbara Kyles's Entrapped (2011) "That one about that burnt-out motherfucker in Alberta blowing up oil tankers" and (ii) David Adams Richards's oeuvre - "A whole bunch by that fella, bleak as fuck, from somewhere in New Brunswick, somewhere around these parts [...] with 
the big long titles where everyone always turns against this one family and someone ends up fucked around in the backwoods or wrongly accused or some such shit" (Burnt 2017: 103). Johnny's reading of Richards tellingly recasts readerly impressions of Burnt itself, just as his boastful reversal of T. S. Eliot's most famous line, from "The Hollow Men" - "cause we're not ending with no fucken whimper tonight are we Johnny?" (Burnt 2017: 114) - ends up as harbinger for his botched hot-tub sex-scene with a classy (albeit wine-drunken, desperate, and married) older, suburban woman at a hotel on the road. The promised "bang" (Burnt 2017: 114) turns out to be about embarrassing incontinence, not cinematic sexual performance.

The intertwining of class tension, masculine performance, and Beatnik romance is not lost on Johnny. Beyond his bravado-sanctioned "rough sex" with Madonna (Burnt 2017: 28), a West coast élite slumming with Johnny a half-world away from her privileged origins, the closest Johnny comes to escaping his lumpenproletariat underworld is his symbolic "indecent exposure" at a house party peopled by that "Crowd there from the university" (Burnt 2017: 34). Complicating the stylistic innovations and representative provocations of canonized heroin romantics and decadents in the western tradition, like Coleridge, De Quincey, Baudelaire, and Rimbaud, and the above-mentioned alternative, modern Beat and Gonzo realists, Johnny has little recourse to lettered pyrotechnics. Johnny therefore more closely reflects an international cast of more recent narcotized heroes, not all of them as popular to readers of English fiction as the renowned outcastes in Irvine Welsh's first novel Trainspotting (1993), not to mention those in the popular oeuvre of Welshman Niall Griffiths. This international character mélange include, for instance, the illiterate, drunken, wife-beating, Joe Lon in Harry Crews' A Feast of Snakes (1975); the speed-balling, homeless, single-mom-of-two Jamie in Denis Johnson's Angels (1977); the unkempt, squalor squatting, heroin-for-breakfast teenager Francisco in António Lobo Antunes' Act of the Damned (1985); the opiated hijra prostitute Dimple in Jeet Thayil's Narcopolis (2012); and, the unsettling, vulgar interiority of the unnamed "girl" in Eimear McBride's A Girl is a Half-Formed Thing (2013). These underclass - or déclassé in Francisco's case figures all occupy that peculiar social (pariah) space more written about from "above" than in situ written from within.

Circulated narratives, historically, have the privilege of appropriating the experiences of these others. Johnny knows this; he understands the top-down dimensions of official narratives. In the first third of Burnt, he twice evokes the limits of his own communication skills: "When he sees her there like this ... well it's like ... he feels ... more acutely than ever in his life his limited vocabulary" (Burnt 2017: 52); and, "Johnny squaring off with him, tryna convey, trying to fucken ... impart, to make this motherfucker understand that Madonna is ... that her ashes are ... Fuck, Johnny wails. Fuck" (Burnt 2017: 89). (A true Canadian, however regionally inscribed, Johnny regularly avails himself of the rhetorical 
potency of a timely uttered "fuck". But he doesn't have the privilege of this epithet being appreciated as a stylized rhetorical flourish.)

I have so far introduced heroin realism, the title of this last section of my essay, only peripherally. Heroin realism, however, works from the periphery - or what Derrida would call an eccentric other centre (1978 [1967]) - to complicate conventional boundaries. Burnt can be critically situated as at once part of and apart from the heroin realism tradition that precedes it. Burnt can be critically located as simultaneously regional and international. What I'd like to finally address is the novel narration of Burnt, a text that can be critically classified as at one and the same time literary and vernacular - like Ulysses, "Howl", and a host of other eventually canonised texts. I have encoded instances of formal ingenuity within my discourse about Burnt by, firstly, characterizing the text as dialogic, and secondly, by simply quoting the reflexive Johnny, who speaks of himself on the one hand in third person ("Johnny", "he") and on the other in first person ("I", "me", the editorial "we"). From the get-go of Burnt, this alternating narratorial point-of-view compels readers to interrogate their reading practices.

As with the "Cyclops" episode in Joyce's Ulysses (1922), Burnt readers come to question their investments in character while they struggle over narrative reliability. Distinct from Joyce's chapter-long exposure of the partiality of storytelling, however, Johnny's underclass perspective is novel-long - and patently self-directed. The narrative conceit of Hynes's Burnt is that it's Johnny's book, a text circulating his own narrative from his own perspective. This is something Hynes himself speaks to when, in a television interview, he notes that "[His own] vocabulary is much better than Johnny's; [his] education is much better than Johnny's. You're confined by your characters' limitations" (YourTV Niagara 2018). In spite of Johnny's socio-regional positioning, which systemically entails his degraded historical placement "among the classes of whites who lack the power to define or shape cultural norms" (Beech 2004: 175), Johnny remains fully aware of the representational norms that delimit "fiction" and "everymen" alike. His everyday miscarriages accumulate on his tragic, epic trans-Canada hitchhike to Vancouver's Jericho Beach. He inexcusably holds the hand, readers remember, of a recovered, old beer fart who lost his son due to drunken neglect. He passes out in a Québec forest after a near-fatal car collision with a moose and wakes with one-side of his face red-ant eaten and the other blistered by an half-day-long sunburn. He discovers his long-romanticized outlaw father is now serving his lifelong-detention for murder in minimum, not in streetcred maximum, security. He's beaten to within an inch of his life by a gaggle of deceptive teenage girls in Winnipeg only to awake in hospital and directly escape, morphine drip in tow, so as to evade his suspected (outcaste Johnny is always already "guilty") police detection. 
Johnny interweaves his depictions of these occurring experiences with memories of past ones. Johnny cannot help but recall - "I remember" (Burnt 2017: 94, 194, 194, 194; "too fucken much I remembers" (Burnt 2017: 194) - the loneliness, violence, and disconnection that haunt his orphaned story. His depressive cousin and best friend Mikey blows his own head off; his adolescence is confined to correctional facilities; he's conceived by Stevie the Scar's rape of the girl he'd always believed to be his sister. Johnny, as a result of these outsider determinations, cannot help but ironically redeem his collapsing, tough-guy masculinity by reflexively deriding - "Fuck off" - his own autobiographical positioning. Not "mere" bravado, so Beardsworth once characterized it (2012: 141), Johnny's aggressive masculinity, one he directs as much to himself as he does to others, appears to be the only agency he has the license to credibly perform. Speaking at once to readers and to versions of himself present and past, over the last half of his memoir, his fateful demise hurrying near, Johnny increasingly iterates versions of "Young John-John, [our] fucken hero" (Burnt 2017: 131, 169, 191, 198, 219, 222).

Johnny's reflexive interruptions evidence his personal opposition to the diminutions implicit in romantic narrative formulations. Johnny's interruptions rhetorically jump out because they involve a resistance to representation in the midst of ongoing self-representation. His flight from a Winnipeg hospital, for instance, is a singular event, not a symbolic one: "I yanks the IV needle outta me hand like the way you sees fellas do it in the movies, like it's this beg rebellious or symbolic act or something. But it's not" (Burnt 2017: 213; my emphasis). The sophistication of this metatextual intervention works precisely because it contributes to what Kurt Spellmeyer would label the complication of top-down "reductions of the subject to an effect of culture, institutions, and economic conditions" (1996: 434). Johnny is not just a flawed Canadian hero overdetermined by the negative endowments of his Newfoundland underclass social realities. Not unlike his author, he invests in books, an investment even smart, underworld others might also read as economically incongruous. Yet "None of it mends nothing", Johnny laments, "You can scour every bookshelf on the planet and you wont come up with not one fucken phrase that changes where you comes from or what you've been up to, been through, who you fucken are" (Burnt 2017: 103). Here, Johnny experiences what bell hooks calls "psychic turmoil" (in Beech 2004: 183). Min-Zhan Lu attributes this phenomenological syndrome to the subject's embodying of "several continuous and conflicting discourses" (in Beech 2004: 183).

Assiduous readers of Canadian fiction might recall the jarring scene early in Alice Munro's "Royal Beatings" where ten-year-old Rose overhears her father reciting Prospero from his backyard workshop: "The cloud-capped towers, the gorgeous palaces” (Munro 1978: 6). Munro's narrator dramatically attests that 
"That was like a hand clapped against Rose's chest, not to hurt, but astonish her, to take her breath away. She had to run then, she had to get away. She knew that was enough to hear, and besides, what if he caught her? It would be terrible" (Munro 1978: 6). The objective correlative is instantly clear to the precocious Rose, if not to the story's expected interpretive community. Read from the bottom-up, Rose's terror is justified. Cultural capital, she learns, is not a guarantor of upward class mobility. (After all, given the public education she's received in West Hanratty, it's likely she originally learned these Shakespeare lines from her father rather than in her schoolroom). Her father's socioeconomic trappings reify the contingencies of Prospero's "As dreams are made on" fatherly speech, wherein the "insubstantial pageant [is] faded" and "melted into air" (Shakespeare 1954 [1621]: 4.1.146-63). Rose apprehends her own conflicted interpellation. Like her father, she inhabits the outcaste environs of West Hanratty. Also like her father, she's astonished to learn, she inhabits a space not customarily conceded to the figure of the underworld subject. She evidences a trained familiarity with the appurtenances of middle-class entitlement - or of what Newfoundlander Sweetland (in Sweetland) might simply call "an air of mainland entitlement" (Crummey 2014: 119).

Rose's trajectory through the ten recollective stories that constitute The Beggar Maid routinely finds her renegotiating her double interpellation. Most evocatively, in "Mischief" Rose's only best friend, Jocelyn, who had studied at the elite Wellesley, confesses that Rose is "interesting to talk to", because she "had ideas but was uneducated" (Munro 1978: 107). When Rose attempts to disabuse Jocelyn by noting that she attended a college in Western Ontario, she's discomfited to grasp that that is precisely what Jocelyn means (Munro 1978: 107). Despite Jocelyn's present economic circumstances - she and her husband are "poor" (Munro 1978: 105) - she can't help but read Rose from the top-down, this even as Jocelyn recognizes that her reduction of Rose is "a romantic notion" (Munro 1978: 106).

Hynes situates the figure of Johnny in such a way as to prohibit similar romantic diminishment, a move Johnny himself rhetorically instantiates by reprimanding his own normativized penchant to fall into the literary (and Canadiana) trap of presenting himself as a "fucken hero" - this whether we read his resistance to heroic portrayal positively or negatively. Though Johnny does fall prey to the complex experience of Canadiana (which involves the nostalgic surrender to a pastoral idyll and the cynical reproof of capitulating to this deluded seduction), we are forced to confront Johnny through the lens of his own lived reality and relationships. Johnny's experiences of the social margins, though individual and unique, though specifically Atlantic Canadian, also speak to outcaste experiences beyond the scope of Canada and Canadiana. Hynes, the Newfoundland bad boy of Canadian literature, fashions Johnny in such a way that 
his vernacular experiences resist regional and national commoditization. Johnny's experiences, and how he himself reflexively relays them, can speak to the lived realities of an international subaltern cast of similarly down-and-out heroin realism misfits, themselves also working to expose shocking socioeconomic ideological entrapments.

\section{REFERENCES}

\section{PRIMARY SOURCES}

Antunes, António Lobo. 1985. Act of the damned. Grove.

Clattenburg, Mike. 2001-2007. Trailer park boys. Halifax: Trailer Park Productions.

Crews, Harry. 1975. A feast of snakes. Atheneum Books.

Crummey, Michael. 2014. Sweetland. Doubleday.

DeLillo, Don. 1971. Americana. Houghton Mifflin Harcourt.

Hynes, Joel Thomas. 2011. Straight razor days. Pedlar Press.

Hynes, Joel Thomas. 2017. We'll all be burnt in our beds some night. Harper.

Johnson, Denis. 1977. Angels. Knopf.

Johnston, Wayne. 1998. The colony of unrequited dreams: A novel. Random House.

Joyce, James. 1922. Ulysses. Sylvia Beach.

Kerouac, Jack. 1957. On the road. Viking Press.

Krazykatie2006. 2010. Tim Hortons commercial (2008). https://www.youtube.com/watch?v=NuFLon $26 \mathrm{nMw}$

Kyles, Barbara. 2011. Entrapped. Rosethorn House.

Laurence, Margaret. 1966. A jest of God. Penguin.

MacLennan, Hugh. 1941. Barometer rising. Penguin.

MacLeod, Alistair. 1999. No great mischief. Vintage.

McBride, Eimear. 2013. A girl is a half-formed thing. Galley Beggar Press.

Moore, Lisa. 2009. February. Chatto \& Windus.

Munro, Alice. 1978. The beggar maid: Stories of Flo \& Rose. Vintage.

Nabokov, Vladimir. 1955. Lolita. Olympia Press.

Proulx, E. Annie. 1993. The shipping news. Simon \& Schuster.

Shakespeare, William. 1954 [1621]. The Tempest. Methuen.

Reimer44. 2008. Tim Hortons commercial. YouTube. 15 January. https://www.youtube.com/watch?v=NuFLon26nMw

Richards, David Adams. 2000. Mercy among the children. Arcade.

Richards, David Adams. 2007. The friends of meager fortune. MacAdam/Cage.

Thayil, Jeet. 2012. Narcopolis. Penguin.

Thompson, Hunter S. 1971. Fear and loathing in Las Vegas. Random House.

Welsh, Irvine. 1993. Trainspotting. Secker \& Warburg.

YourTV Niagara. 2018. Joel Thomas Hynes. YouTube. 21 November. https://www.youtube.com/watch?v=O2IBY6vGdWo 


\section{SECONDARY SOURCES}

Beardsworth, Adam. 2012. Straight Razor Days: Review. Newfoundland and Labrador Studies 27.1. 141-143.

Beech, Jennifer. 2004. Redneck and hillbilly discourse in the writing classroom: Classifying critical pedagogies of whiteness. College English 67(2). 172-186. DOI: 10.2307/4140716

Butler Hallet, Michelle. 2009. Bottle pit: An interview with Joel Thomas Hynes. Antigonish Review 157. 121-135.

Carter, Susan. 2017. Newfoundland and Joel Thomas Hynes: Writing about a place he loves. The Star. 1 April. Np.

Creelman, David. 2003. Setting in the east: Maritime realist fiction. McGill-Queen's University Press.

Derrida, Jacques. 1978 [1967]. Writing and difference. Chicago University Press.

Genette, Gérard. 1997. Paratexts: Thresholds of interpretation. Cambridge University Press.

Hartigan, John, Jr. 1997. Locating white Detroit. In Ruth Frankenburg (ed.), Displacing whiteness: Essays in social and cultural criticism. Durham University Press. 180-213.

hooks, bell. 1994. Teaching to transgress: Education as the practice of freedom. Routledge.

Hughes-Fuller, Patricia. 2009. Wild bodies and true lies: Carnival, spectacle, and the curious case of Trailer Park Boys. Canadian Journal of Communication 34(1). 95-109. DOI: cjc.2009v34n1a2169

Hurley, Melanie. 2018. Book review of Joel Thomas Hynes's We'll all be burnt in our beds some night. Newfoundland \& Labrador Studies 33(1). 283-287.

Lawrence, Adam. 2010. Riots, referendums, and raging fires: Revisiting history in recent Newfoundland fiction. Newfoundland \& Labrador Studies 25(1). 129-139.

McKay, Ian. 1994. The quest of the folk: Antimodernism and cultural selection in twentieth-century Nova Scotia. McGill-Queen's University Press.

Spellmeyer, Kurt. 1996. Review: Out of the fashion industry: From cultural studies to the anthropology of knowledge. College Composition and Communication 47(3). 424434. DOI: $10.2307 / 358301$

Thompson, Peter. 2015. The Mississippi of the North: Trailer Park Boys and race in contemporary Nova Scotia. Journal of Canadian Studies 49(1). 180-204. DOI: 10.3138/jcs.49.1.180

Tremblay, Tony. 2008. 'Lest on too close sight I miss the darling illusion': The politics of the centre in 'Reading Maritime.' Studies in Canadian Literature 33(2). 23-39.

Wozniak, Jesse S. G. 2014. When the going gets weird: An invitation to gonzo sociology. The American Sociologist 45. 453-473. DOI: 10.1007/s12108-014-9242-9

Wyile, Herb. 2008. Going out of their way: Tourism, authenticity, and resistance in contemporary Atlantic-Canadian literature. English Studies in Canada 34(2-3). 159-180.

Wyile, Herb. 2010. February is the cruelest month: Neoliberalism and the economy of mourning in Lisa Moore's February. Newfoundland \& Labrador Studies 25(1). 55-71. DOI: 10.1353/esc. 0.0114

Wyile, Herb. 2011. Anne of Tim Hortons: Globalization and the reshaping of Atlantic Canadian literature. Wilfred Laurier University Press.

Wyile, Herb. 2013. Neoliberalism, austerity, and the academy. English Studies in Canada 39(4). 29-31.

Wyile, Herb, \& Jeanette Lynes. 2008. Surf's up! The rising tide of Atlantic-Canadian literature. Studies in Canadian Literature 33(2). 5-22. 